\title{
Problems Faced by Micro, Small and Medium Enterprises - A Special Reference to Small Entrepreneurs in Erode District
}

\author{
V. Usha Rani* \\ P.G. and Research Department of Economics, Chikkaiah Naicker College, Erode - 638004, India; \\ professorusharani@gmail.com
}

\begin{abstract}
The Micro, Small and Medium Enterprises (MSMEs) are playing a momentous role in the overall economic development of our country where millions of people are unemployed or under-employed. Poverty and unemployment are two burning problems of the country today. The MSMEs play a vital role in the growth of the country. The MSMEs sector contributes significantly to the manufacturing output, employment and exports of the country. The strategy of economic development of any country that formulates programmes for removal of poverty by providing large scale employment, capital formation, effective mobilization of resources, balanced economic growth, expansion of trade and equitable distribution of national income with effective involvement and participation of all its citizens in the accomplishment of the goal, cannot neglect MSMEs Sector. This sector faces so many problems while competing with other large scale industries. If these problems are solved or efforts are taken to foster these challenges, this sector can prove itself as a developing engine. This paper deals with the identification of problems of the MSMEs and the study is empirical in nature based on the survey of $340 \mathrm{MSME}$ units situated and working in the Erode district.
\end{abstract}

Keywords: Balanced Economic Growth, Capital Formation, Economic Development, Large Scale Employment, National Income, Removal of Poverty, MSMEs

\section{Introduction}

Lack of capital, excessive dependence on agriculture and abundant supply of manpower are the characteristic features of many developing countries in Asia. Hence, small scale sector is the most suitable one for these economies. In India, the Micro, Small and Medium Enterprises (MSMEs) play a crucial role in the overall development process.

The term 'MSME' is normally used to describe small industrial or business units in the private sector. MSMEs have been classified differently in different contexts in terms of their nature of assets and scale of production etc., while others have defined those units in terms of employment generation, shareholders' funds, scale of investment or sale of products etc.

The enactment of Micro, Small and Medium Enterprises Development (MSMED) Act, in 2006 by the Government of India gave a legal basis and framework to the micro, small and medium enterprises by defining and classifying these enterprisers on a uniform basis 1 . This classification covers industries both under manufacturing and service sector and the limits are excluding the cost of land, building and other specified items.
Classification of MSMEs based on Investment Slabs

\begin{tabular}{|l|l|}
\hline \multicolumn{2}{|c|}{ MANUFACTURING ENTERPRISES } \\
\hline Enterprises & Investment in Plant and Machineries \\
\hline Micro & Up to Rs. 25 Lakhs \\
\hline Small & More than Rs. 25 Lakhs and up to Rs. 5 Crores \\
\hline Medium & More than Rs. 5 Crores and up to Rs. 10 Crores \\
\hline & SERVICE ENTERPRISES \\
\hline Enterprises & Investment in Equipments \\
\hline Micro & Up to Rs. 10 Lakhs \\
\hline Small & More than Rs. 10 Lakhs and up to Rs. 2 Crores \\
\hline Medium & More than Rs. 2 Crores and up to Rs. 5 Crores \\
\hline
\end{tabular}

Source: Micro, Small and Medium Enterprises Development Act, 2006. 
The growth and development of MSME sector in our country has been consistent and remarkable over the preceding decades. However, this sector is not without problems. Therefore, the present study throws some light on its performance and the problems.

\section{Literature Review}

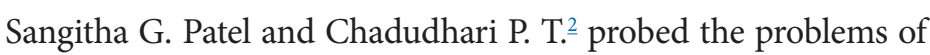
S.S.I in India in general, but not relating to any particular State or Region. Vasu M. S. and Jayachandra K. -3 analysed the growth and performance of MSMEs in India in general. Shiralashetti A. S. ${ }^{4}$ exposed the growth, performance and contribution of MSMEs to GDP in Dharwad district of Karnataka State. Rajib Lahiri ${ }^{5}$ critically analyzed to explore the opportunities enjoyed and the constraints faced by MSMEs in India during the pre and post liberalization period. Padmasani and Karthika S. .6 examined the problems of MSMEs in the era of global economy and also identified the factors affecting them with special reference to textile exports. Nishanth P. and Zakkariya K. A. ${ }^{7}$ reviewed various barriers faced by MSME units in raising finance. Neeru Garg ${ }^{8}$ highlighted the growth, problems and the challenges witnessed by MSME sector in India in general. Suneetha K. and Sankaraiah T. ${ }^{-}$investigated the problems of MSMEs in the Kadapa district, of Andrapradesh. Aruna H. N..$^{10}$ attempted to highlight the problems faced by MSMEs in Visakhapatnam. Israr Ahmed ${ }^{11}$ examined the problems and prospects of MSMEs in J \& K.

\section{Objectives}

The main objectives of the present study are:

- To examine the growth and performance of MSME sector in India.

- To analyse the problems of MSMEs in Erode district.

\section{Significance of the Study}

This study is confined to MSME units of five industries namely, Agro based industries, Chemical based industries, Textile based industries, Mineral based industries, and Engineering and Allied industries, which are located in the Erode district, since the major objective of this study is to examine the problems of the MSMEs based on the sample respondents in the study area covering a period of ten years from 2007-2008 to 2017-2018. Hence, the findings of this study can be used by industrial houses, prospective entrepreneurs and policy makers to take better business decisions.

\section{Sampling Design and Data Collection}

On the basis of group-wise classification done by the Department of Industries and Commerce, Government of Tamil Nadu, five classifications of MSME units in Erode district were taken up for study. These classifications were considered as five broad Vol 5(1) | January-June 2018 | strata namely Agro based industries, Chemical based industries, Textile based industries, Mineral based industries and Engineering and Allied industries. The required data were collected by employing stratified random sampling technique, using proportional allocation whereby, the size of the sample from different strata was kept proportional to the stratum size.

A sample size of more than 300 is considered to be a representative sample which significantly reduces the standard error of the coefficient of most of the variables. Hence the sample size was fixed as 340 . The population size $(\mathrm{P})$ is $23343, \mathrm{P}_{\mathrm{i}}$ represents the proportion of population included in stratum $i$ and $n$ represents the total sample size. Therefore the number of items selected from stratum $\mathrm{i}$ is $n \mathrm{P}_{\mathrm{i}}$

$$
\begin{aligned}
\text { Agro based industries }\left(n_{1}\right) & =340 \times 6704 / 23343 \\
\text { Chemical based industries }\left(n_{2}\right) & =97 \\
\text { Textile based industries }\left(n_{3}\right) & =340 \times 1375 / 23343 \\
& =340 \times 8911 / 23343 \\
\text { Mineral based industries }\left(n_{4}\right) & =130 \\
\text { Engineering and Allied industries }\left(n_{5}\right) & =340 \times 3545 / 23343 \\
& =52 \\
\text { The Sample Size } & =41 \\
& =340
\end{aligned}
$$

Out of a total of 23343 MSMEs, using simple random sampling technique, the sample respondents were selected accordingly from each stratum. The number of select sample respondents included-Agro based industries $\left(n_{1}\right)=97$, Chemical based industries $\left(n_{2}\right)=20$, Textile based industries $\left(n_{3}\right)=130$, Mineral based industries $\left(n_{4}\right)=52$, Engineering and Allied industries $\left(n_{5}\right)=41$. Thus, a total of 340 sample respondents were selected for the study. The necessary primary data were collected from the sample respondent firms by using a well-structured interview schedule during January to May 2018. Besides, the secondary data related to the MSME sector was tapped from its annual reports in order to analyse its growth and performance.

\section{Tools of Analysis}

For the purpose of analysis, the Composite Weighted Score method was used. Under this method different alternatives have been assigned weights in the order of preference. MSMEs' problems were analysed by using Likert's Five Point Scaling technique. As per the opinion of the industrialists, scores were assigned and weights were given for all the five types of sample units.

WEIGHTS ASSIGNED: Very high +2 ; High +1 ;
Normal 0; Low -1 ; Very low -2 ;
Score: SC = F X W FINANCE PROBLEMS,
PRODUCTION PROBLEMS and LABOUR
PROBLEMS
Coefficient: SC/N; where $n$ is the total number
of respondents




\section{Growth and Performance of Small Scale Industries in India}

The Government of India has introduced several major policy initiatives for the support and promotion of micro, small and medium enterprises in the country. These include the establishment of Small Industries Development Bank of India (SIDBI) in 1990 for promotion and financing of MSME sector, Credit Guarantee Fund Trust of Micro and Small Enterprises (CGTMSE) in 2000 to offer credit facilities to eligible borrowers and the Prime Minister's Employment Generation Programme (PMEGP) in 2008 to gener- ate employment opportunities in rural and urban areas through new self-employment ventures/projects/micro enterprises. Table 1 reveals the number of working enterprises, employment generated and the investments in fixed assets in the MSME sector of India as disclosed in the Fourth All India Census of MSME-2015-2016 $\frac{12}{20}$ denote its performance and the growth rate.

It is obvious to note from Table 1 that the MSME sector in India had registered a moderate annual compound growth rate of $6.43 \%$ in terms of total working enterprises, $3.63 \%$ in terms of employment generated and $6.04 \%$ in terms of market value of fixed assets held over a period of ten years between 2006-07 and 2015-16.

Table 1. Performance of MSME Sector in India

\begin{tabular}{|c|c|c|c|}
\hline Year & $\begin{array}{c}\text { Total Working } \\
\text { Enterprises } \\
\text { (Nos. in lakh) }\end{array}$ & Employment Generated (Nos. in lakh) & $\begin{array}{c}\text { Market Value of fixed Assets } \\
\text { (Rs. in Crores) }\end{array}$ \\
\hline $2006-07$ & 361.76 & 805.23 & $868,546.79$ \\
\hline $2007-08$ & 377.36 & 842.00 & $920,459.84$ \\
\hline $2008-09$ & 393.70 & 880.84 & $977,144.72$ \\
\hline $2009-10$ & 410.80 & 921.79 & $1,038,546.08$ \\
\hline $2010-11$ & 428.73 & 965.15 & $1,105,934.09$ \\
\hline $2011-12$ & 447.64 & $1,011.69$ & $1,182,757.84$ \\
\hline $2012-13$ & 447.54 & $1,061.40$ & $1,268,763.67$ \\
\hline $2013-14$ & 488.46 & $1,114.29$ & $1,363,700.54$ \\
\hline $2014-15$ & 510.57 & $1,171.32$ & $1,471,992.94$ \\
\hline $2015-16$ & 633.88 & 1109.89 & $1,471,912.94$ \\
\hline CAGR & $\mathbf{6 . 4 3 \%}$ & $3.63 \%$ & $\mathbf{6 . 0 4 \%}$ \\
\hline
\end{tabular}

Source: Annual Report of MSME, Government of India, 2015-16.

\section{Major Problems and Prospects of Micro, Small and Medium Enterprises in Erode District}

\subsection{Production Problem}

Normally business firms face many problems relating to production. These problems include scarcity of raw material, high cost of raw materials, poor quality, shortage of power, high cost of power, absolete technology and transportation problem. These problems are analysed by using Likert's Five Point Scaling technique. The opinion of the industrialists, scores assigned and the weights given are presented for all the five types of sample units in Tables $2 \mathrm{~A}$ to $2 \mathrm{E}$.
An industry cannot function effectively and successfully without adequate and cheap supply of raw materials. Based on the scores and the co-efficient, production problems of the select sample industries are given rank as shown in Table $2 \mathrm{~A}$ to $2 \mathrm{E}$. 'Nonavailability of raw materials' is ranked first in case of Chemical based, Textile based and Mineral based industries. 'High cost of raw materials' is ranked second in case of Chemical based and Mineral based industries. Third rank is assigned to high cost of power' in case of Agro based and Mineral based industries followed by 'poor quality of raw materials' as experienced by Chemical and Mineral based industries. Fourth rank is given for 'non-availability of power' in case of textile based industries. However, the analysis brings to light that the most important and serious problem is 'non-availability and high cost of raw materials'.

Table 2A. Production Problems

\begin{tabular}{|c|c|c|c|c|c|c|c|c|c|}
\hline \multicolumn{10}{|c|}{ Agro Based Industries } \\
\hline $\begin{array}{l}\text { Non-availability of Raw } \\
\text { Materials }\end{array}$ & 16 & 34 & 30 & 6 & 12 & 98 & 36 & 0.367 & 2 \\
\hline $\begin{array}{l}\text { Higher cost of Raw } \\
\text { Materials }\end{array}$ & 7 & 48 & 32 & 5 & 6 & 98 & 45 & 0.459 & 1 \\
\hline
\end{tabular}




\begin{tabular}{|c|c|c|c|c|c|c|c|c|c|}
\hline \multicolumn{10}{|c|}{ Agro Based Industries } \\
\hline $\begin{array}{l}\text { Poor quality of Raw } \\
\text { Materials }\end{array}$ & 8 & 26 & 45 & 9 & 10 & 98 & 13 & 0.133 & 6 \\
\hline $\begin{array}{l}\text { Non-availability of } \\
\text { Power }\end{array}$ & 11 & 31 & 35 & 9 & 12 & 98 & 20 & 0.204 & 4 \\
\hline $\begin{array}{l}\text { Higher cost of } \\
\text { Technology }\end{array}$ & 10 & 29 & 33 & 17 & 9 & 98 & 14 & 0.143 & 5 \\
\hline $\begin{array}{l}\text { Higher transport cost of } \\
\text { raw materials }\end{array}$ & 13 & 22 & 34 & 20 & 9 & 98 & 10 & 0.102 & 7 \\
\hline
\end{tabular}

Source: Primary data

Table 2B. Production Problems

\begin{tabular}{|l|c|c|c|c|c|c|c|c|c|}
\hline \multicolumn{10}{|c|}{ Chemical Based Industries } \\
\hline \multicolumn{1}{|c|}{ Production problems } & Very High & High & Normal & Low & Very Low & N & SC & Co-eff. & Rank \\
\hline Non-availability of Raw Materials & 5 & 8 & 4 & 3 & 0 & 20 & 15 & 0.750 & 1 \\
\hline Higher cost of Raw Materials & 2 & 11 & 6 & 1 & 0 & 20 & 14 & 0.700 & 2 \\
\hline Poor quality of Raw Materials & 1 & 6 & 10 & 3 & 0 & 20 & 5 & 0.251 & 4 \\
\hline Non-availability of Power & 2 & 8 & 5 & 3 & 2 & 20 & 5 & 0.250 & 5 \\
\hline Higher cost of Power & 1 & 5 & 8 & 3 & 3 & 20 & -2 & -0.100 & 8 \\
\hline Non-availability of Technology & 2 & 4 & 10 & 4 & 0 & 20 & 4 & 0.201 & 6 \\
\hline Higher cost of Technology & 3 & 9 & 5 & 3 & 0 & 20 & 12 & 0.600 & 3 \\
\hline $\begin{array}{l}\text { Higher transport cost of raw } \\
\text { materials }\end{array}$ & 3 & 1 & 13 & 3 & 0 & 20 & 4 & 0.200 & 7 \\
\hline Others & 1 & 4 & 4 & 2 & 9 & 20 & -14 & -0.700 & 9 \\
\hline
\end{tabular}

Source: Primary data

Table 2C. Production Problems

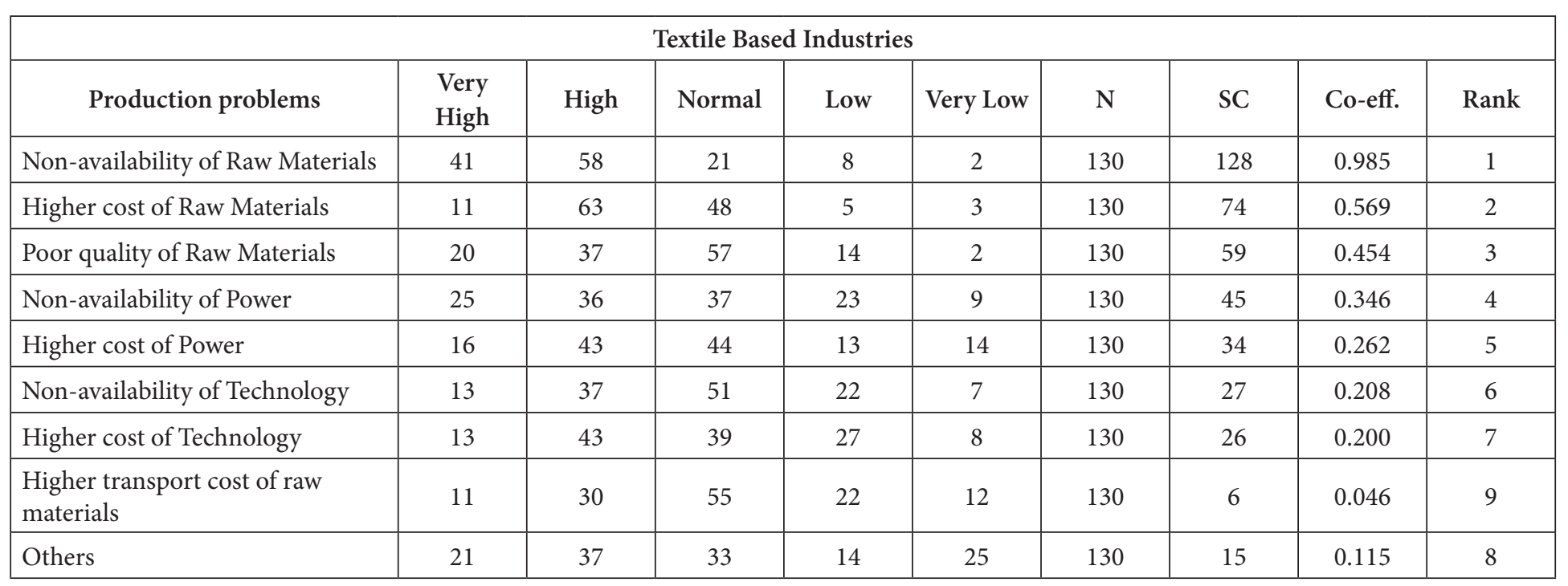

Source: Primary data 
Table 2D. Production Problems

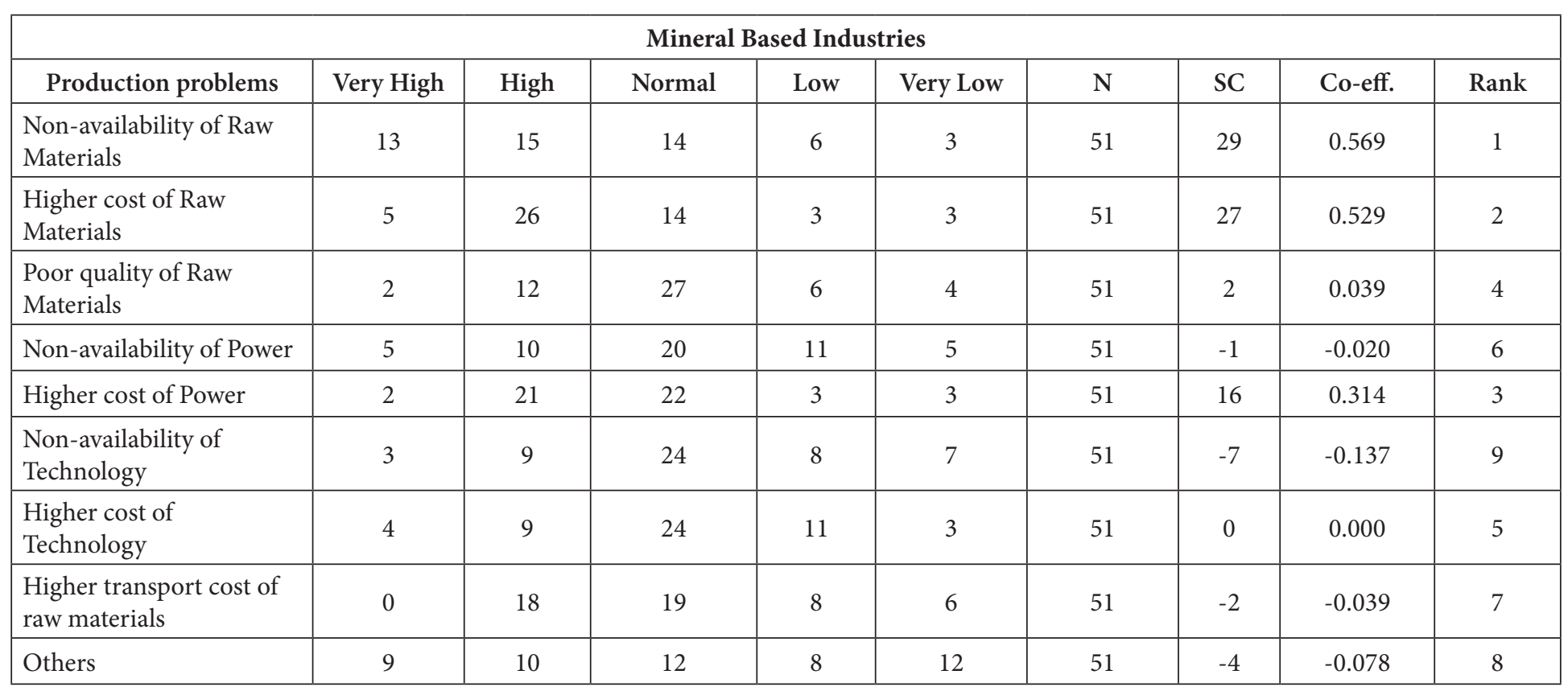

Source: Primary data

Table 2E. Production Problems

\begin{tabular}{|c|c|c|c|c|c|c|c|c|c|}
\hline \multicolumn{10}{|c|}{ Engineering and Allied Industries } \\
\hline Production problems & Very High & High & Normal & Low & Very Low & $\mathrm{N}$ & SC & Co-eff. & Rank \\
\hline $\begin{array}{l}\text { Non -availability of Raw } \\
\text { Materials }\end{array}$ & 7 & 9 & 15 & 9 & 1 & 41 & 12 & 0.293 & 4 \\
\hline $\begin{array}{l}\text { Higher cost of Raw } \\
\text { Materials }\end{array}$ & 2 & 18 & 18 & 2 & 1 & 41 & 18 & 0.439 & 1 \\
\hline $\begin{array}{l}\text { Poor quality of Raw } \\
\text { Materials }\end{array}$ & 2 & 10 & 20 & 7 & 2 & 41 & 3 & 0.074 & 7 \\
\hline Non-availability of Power & 2 & 14 & 15 & 8 & 2 & 41 & 6 & 0.146 & 6 \\
\hline Higher cost of Power & 1 & 18 & 16 & 5 & 1 & 41 & 13 & 0.317 & 2 \\
\hline $\begin{array}{l}\text { Non-availability of } \\
\text { Technology }\end{array}$ & 2 & 11 & 15 & 9 & 4 & 41 & -2 & -0.049 & 9 \\
\hline Higher cost of Technology & 2 & 7 & 25 & 6 & 1 & 41 & 3 & 0.073 & 8 \\
\hline
\end{tabular}

Source: Primary data

\subsection{Labour Problem}

The respondents were asked to express their opinion about the problems relating to labour in their organisations. The problems include non-availability of skilled persons, cost of labour, cost of retaining, cost of perquisites, absenteeism, sickness of labour, union problems, government intervention, inspection by officials and others. The data collected in this regard are shown for all the five types of sample units in Tables $3 \mathrm{~A}$ to $3 \mathrm{E}$.

It is clear from Table 3A that in Agro based industries, 'problem given by trade unions' or 'labour unrest' occupies the first place as the co-efficient is 0.653 . 'Frequent inspection by officials' occupies the second place as the co-efficient is 0.633 followed by 'non-availability of skilled persons' with co-efficient of 0.622 . 'Interference of the Government' often affects smooth working of these industries and hence is given fourth rank with a co-efficient of 0.531 . 'Retention of labour' and 'Cost of labour' also pose a threat to these industries which occupy the fifth and the sixth place respectively.

It is obvious from Table $3 \mathrm{~B}$ that in case of Chemical based industries, the problem of 'non-availability of skilled person' occupies the first place with a co-efficient of 0.850 . 'Cost of retaining labour' occupies the second place as the co-efficient of 0.500 followed by 'cost of labour' with a co-efficient of 0.450 . 'Absenteeism 
of labour' is given the fourth rank with a co-efficient of 0.150 . 'Cost of perquisites' and 'sickness of labour' also pose a threat to these industries which occupy the fifth and the sixth place respectively.

Table 3C shows that in case of Textile based industries, 'non-availability of skilled persons' occupies the first place with a co-efficient of 0.915 . 'Cost of perquisites' occu- pies the second place as the co-efficient is 0.723 followed by 'Government intervention' with a co-efficient of 0.669. 'Union problems' is given the fourth rank with a co-efficient of 0.654 . 'Inspection by officials' and 'cost of labour' also pose a threat to these industries which occupy the fifth and the sixth place respectively.

Table 3A. Labour Problems

\begin{tabular}{|c|c|c|c|c|c|c|c|c|c|}
\hline \multicolumn{10}{|c|}{ Agro Based Industries } \\
\hline Labour problems & Very High & High & Normal & Low & Very Low & $\mathbf{N}$ & SC & Co-eff. & Rank \\
\hline $\begin{array}{l}\text { Non-availability of skilled } \\
\text { persons }\end{array}$ & 18 & 39 & 32 & 4 & 5 & 98 & 61 & 0.622 & 3 \\
\hline Cost of Labour & 7 & 49 & 29 & 9 & 4 & 98 & 46 & 0.469 & 6 \\
\hline Cost of retaining & 13 & 39 & 36 & 5 & 5 & 98 & 50 & 0.510 & 5 \\
\hline Absenteeism & 18 & 27 & 38 & 7 & 8 & 98 & 40 & 0.408 & 8 \\
\hline Sickness of labour & 28 & 15 & 39 & 7 & 9 & 98 & 46 & 0.469 & 7 \\
\hline Union problems & 43 & 11 & 26 & 3 & 15 & 98 & 64 & 0.653 & 1 \\
\hline Government intervention & 36 & 13 & 31 & 3 & 15 & 98 & 52 & 0.531 & 4 \\
\hline
\end{tabular}

Source: Primary data

Table 3B. Labour Problems

\begin{tabular}{|c|c|c|c|c|c|c|c|c|c|}
\hline \multicolumn{10}{|c|}{ Chemical Based Industries } \\
\hline Labour problems & Very High & High & Normal & Low & Very Low & $\mathrm{N}$ & SC & Co-eff. & Rank \\
\hline $\begin{array}{l}\text { Non-availability of skilled } \\
\text { persons }\end{array}$ & 5 & 8 & 6 & 1 & 0 & 20 & 17 & 0.850 & 1 \\
\hline Cost of Labour & 0 & 10 & 9 & 1 & 0 & 20 & 9 & 0.450 & 3 \\
\hline Cost of retaining & 1 & 10 & 8 & 0 & 1 & 20 & 10 & 0.500 & 2 \\
\hline Absenteeism & 2 & 3 & 11 & 4 & 0 & 20 & 3 & 0.150 & 4 \\
\hline Sickness of labour & 0 & 6 & 10 & 3 & 1 & 20 & 1 & 0.050 & 6 \\
\hline Union problems & 2 & 1 & 11 & 6 & 0 & 20 & -1 & -0.050 & 7 \\
\hline Government intervention & 1 & 2 & 10 & 5 & 2 & 20 & -5 & -0.250 & 8 \\
\hline
\end{tabular}

Source: Primary data

Table 3C. Labour Problems

\begin{tabular}{|c|c|c|c|c|c|c|c|c|c|}
\hline \multicolumn{10}{|c|}{ Textile Based Industries } \\
\hline Labour problems & Very High & High & Normal & Low & Very Low & $\mathbf{N}$ & SC & Co-eff. & Rank \\
\hline $\begin{array}{l}\text { Non-availability of skilled } \\
\text { persons }\end{array}$ & 37 & 55 & 31 & 4 & 3 & 130 & 119 & 0.915 & 1 \\
\hline Cost of Labour & 9 & 66 & 42 & 8 & 5 & 130 & 66 & 0.508 & 6 \\
\hline
\end{tabular}




\begin{tabular}{|l|c|c|c|c|c|c|c|c|c|}
\hline \multicolumn{10}{|c|}{ Textile Based Industries } \\
\hline \multicolumn{1}{|c|}{ Labour problems } & Very High & High & Normal & Low & Very Low & N & SC & Co-eff. & Rank \\
\hline Cost of retaining & 12 & 47 & 59 & 9 & 3 & 130 & 56 & 0.431 & 7 \\
\hline Cost of perquisites & 29 & 48 & 45 & 4 & 4 & 130 & 94 & 0.723 & 2 \\
\hline Absenteeism & 17 & 34 & 49 & 20 & 10 & 130 & 28 & 0.215 & 9 \\
\hline Sickness of labour & 23 & 33 & 50 & 17 & 7 & 130 & 48 & 0.369 & 8 \\
\hline Union problems & 52 & 13 & 40 & 18 & 7 & 130 & 85 & 0.654 & 4 \\
\hline Government intervention & 37 & 29 & 49 & 14 & 1 & 130 & 87 & 0.669 & 3 \\
\hline Inspection by officials & 47 & 18 & 41 & 15 & 9 & 130 & 79 & 0.608 & 5 \\
\hline Others & 19 & 11 & 11 & 75 & 14 & 130 & -54 & -0.415 & 10 \\
\hline
\end{tabular}

Source: Primary data

Table 3D. Labour Problems

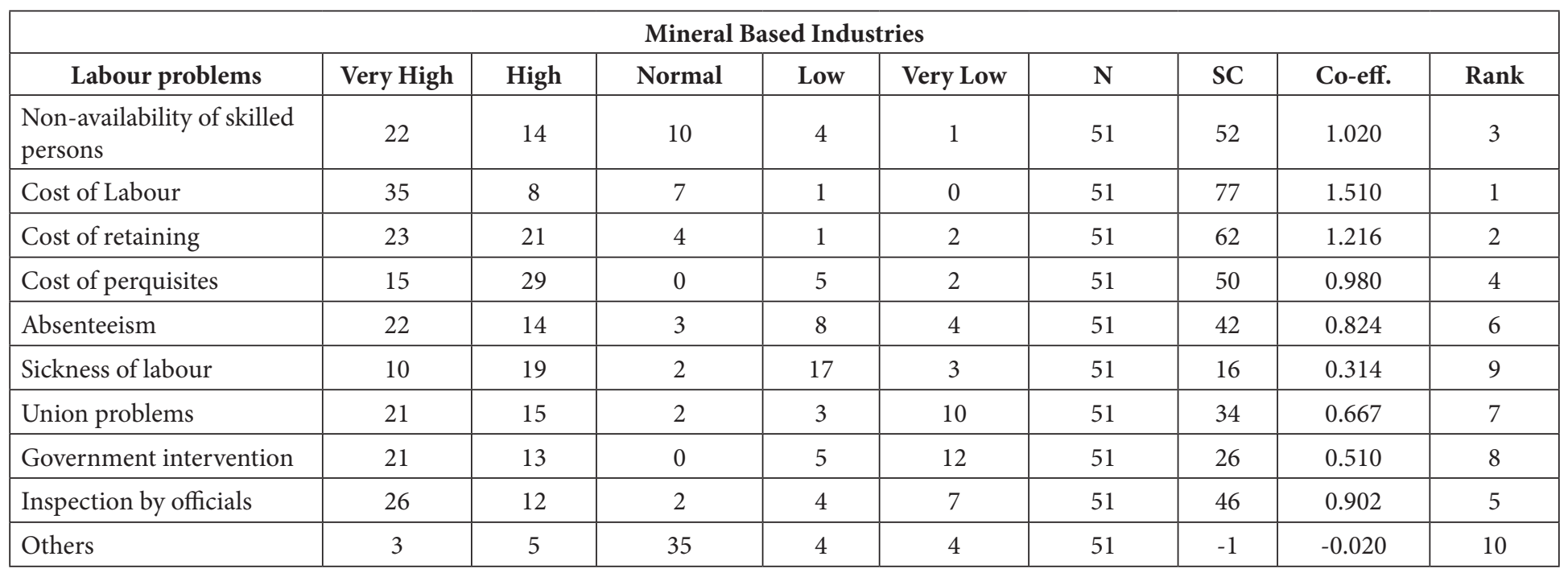

Source: Primary data

Table 3E. Labour Problems

\begin{tabular}{|l|c|c|c|c|c|c|c|c|c|}
\hline \multicolumn{10}{|c|}{ Engineering and Allied industries } \\
\hline \multicolumn{1}{|c|}{ Labour problems } & Very High & High & Normal & Low & Very Low & N & SC & Co-eff. & Rank \\
\hline $\begin{array}{l}\text { Non - availability of skilled } \\
\text { persons }\end{array}$ & 21 & 1 & 15 & 3 & 1 & 41 & 38 & 0.927 & 3 \\
\hline Cost of Labour & 23 & 5 & 11 & 1 & 1 & 41 & 48 & 1.171 & 1 \\
\hline Cost of retaining & 24 & 0 & 15 & 1 & 1 & 41 & 45 & 1.098 & 2 \\
\hline Cost of perquisites & 10 & 0 & 25 & 5 & 1 & 41 & 13 & 0.317 & 8 \\
\hline Absenteeism & 14 & 5 & 11 & 9 & 2 & 41 & 20 & 0.488 & 6 \\
\hline Sickness of labour & 10 & 6 & 6 & 18 & 1 & 41 & 6 & 0.146 & 9 \\
\hline Union problems & 20 & 2 & 4 & 7 & 8 & 41 & 19 & 0.463 & 7 \\
\hline Government intervention & 19 & 2 & 7 & 7 & 6 & 41 & 21 & 0.512 & 5 \\
\hline Inspection by officials & 21 & 2 & 6 & 7 & 5 & 41 & 27 & 0.659 & 4 \\
\hline Others & 7 & 6 & 4 & 4 & 20 & 41 & -24 & -0.585 & 10 \\
\hline
\end{tabular}

Source: Primary data 
Table 3D discloses that in case of Mineral based industries, 'cost of labour' occupies the first place as the co-efficient is 1.510. 'Cost of retaining' occupies the second place as the co-efficient is 1.216 followed by 'non-availability of skilled persons' with a co-efficient of 1.020. 'Cost of perquisites' is given the fourth rank as the co-efficient is 0.980 . 'Inspection by officials' and 'absenteeism of labour' also pose a threat to these industries which occupy the fifth and the sixth place respectively.

Table 3E exposes that in case of Engineering and Allied industries, 'cost of labour' occupies the first place as the co-efficient is 1.171. 'Cost of retaining' occupies the second place with a co-efficient of 1.098 followed by 'non-availability of skilled persons' with a co-efficient of 0.927 . 'Inspection by officials' is given the fourth rank with a co-efficient of 0.659 . 'Government intervention' and 'absenteeism of labour' also pose a threat to these industries which occupy the fifth and the sixth place respectively.

\subsection{Problem of Finance}

Finance is the life blood of any organisation to sustain and progress. Finance is a common problem existing in most of the firms of SSIs as these firms are unable to raise the required and timely funds due to low credit worthiness. This in turn restrains them from planning for modernization, expansion and diversification. The data relating to the problem of finance has been analysed by using Likert's Five Point Scaling Technique. The opinions collected, scores assigned and the weights given are presented for all the five types of sample units in Tables $4 \mathrm{~A}$ to $4 \mathrm{E}$.

Table 4A. Problem of Finance

\begin{tabular}{|c|c|c|c|c|c|c|c|c|c|}
\hline \multicolumn{10}{|c|}{ Agro Based Industries } \\
\hline Finance problems & Very High & High & Normal & Low & Very Low & $\mathbf{N}$ & SC & Co-eff. & Rank \\
\hline $\begin{array}{l}\text { Non-availability of fixed } \\
\text { capital }\end{array}$ & 31 & 24 & 18 & 7 & 18 & 98 & 43 & 0.439 & 2 \\
\hline High Rate of interest & 11 & 37 & 25 & 10 & 15 & 98 & 19 & 0.194 & 3 \\
\hline $\begin{array}{l}\text { Non-availability of finance } \\
\text { in time }\end{array}$ & 13 & 18 & 39 & 13 & 15 & 98 & 1 & 0.010 & 4 \\
\hline Penal interest & 38 & 16 & 17 & 7 & 20 & 98 & 45 & 0.459 & 1 \\
\hline Others & 19 & 15 & 31 & 8 & 25 & 98 & -5 & -0.051 & 5 \\
\hline
\end{tabular}

Source: Primary data

Table 4B. Problem of Finance

\begin{tabular}{|c|c|c|c|c|c|c|c|c|c|}
\hline \multicolumn{10}{|c|}{ Chemical Based Industries } \\
\hline $\begin{array}{l}\text { Non-availability of fixed } \\
\text { capital }\end{array}$ & 11 & 4 & 2 & 1 & 2 & 20 & 21 & 1.050 & 1 \\
\hline High Rate of interest & 7 & 5 & 3 & 2 & 3 & 20 & 11 & 0.550 & 2 \\
\hline $\begin{array}{l}\text { Non-availability of finance } \\
\text { in time }\end{array}$ & 4 & 7 & 4 & 3 & 2 & 20 & 8 & 0.400 & 4 \\
\hline Penal interest & 4 & 4 & 5 & 3 & 4 & 20 & 1 & 0.050 & 5 \\
\hline Others & 4 & 3 & 4 & 6 & 3 & 20 & -1 & -0.050 & 6 \\
\hline
\end{tabular}

Source: Primary data

Table 4C. Problem of Finance

\begin{tabular}{|c|c|c|c|c|c|c|c|c|c|}
\hline \multicolumn{10}{|c|}{ Textile Based Industries } \\
\hline $\begin{array}{l}\text { Non-availability of fixed } \\
\text { capital }\end{array}$ & 41 & 26 & 23 & 8 & 32 & 130 & 36 & 0.277 & 2 \\
\hline High Rate of interest & 31 & 34 & 35 & 9 & 21 & 130 & 45 & 0.346 & 1 \\
\hline $\begin{array}{l}\text { Non-availability of finance } \\
\text { in time }\end{array}$ & 13 & 40 & 43 & 5 & 29 & 130 & 3 & 0.023 & 4 \\
\hline
\end{tabular}




\begin{tabular}{|l|c|c|c|c|c|c|c|c|c|}
\hline \multicolumn{10}{|c|}{ Textile Based Industries } \\
\hline \multicolumn{1}{|c|}{ Finance problems } & Very High & High & Normal & Low & Very Low & N & SC & Co-eff. & Rank \\
\hline Inadequate finance & 28 & 20 & 42 & 18 & 22 & 130 & 14 & 0.108 & 3 \\
\hline Penal interest & 22 & 25 & 33 & 10 & 40 & 130 & -21 & -0.162 & 6 \\
\hline Others & 11 & 27 & 54 & 19 & 19 & 130 & -8 & -0.062 & 5 \\
\hline
\end{tabular}

Source: Primary data

Table 4D. Problem of Finance

\begin{tabular}{|c|c|c|c|c|c|c|c|c|c|}
\hline \multicolumn{10}{|c|}{ Mineral Based Industries } \\
\hline Finance problems & Very High & High & Normal & Low & Very Low & $\mathbf{N}$ & SC & Co-eff. & Rank \\
\hline $\begin{array}{l}\text { Non-availability of fixed } \\
\text { capital }\end{array}$ & 15 & 14 & 7 & 11 & 4 & 51 & 25 & 0.490 & 1 \\
\hline High Rate of interest & 13 & 7 & 13 & 12 & 6 & 51 & 9 & 0.176 & 2 \\
\hline $\begin{array}{l}\text { Non-availability of finance } \\
\text { in time }\end{array}$ & 8 & 6 & 24 & 4 & 9 & 51 & 0 & 0.000 & 4 \\
\hline Penal interest & 11 & 5 & 13 & 15 & 7 & 51 & -2 & -0.039 & 5 \\
\hline Others & 5 & 10 & 4 & 8 & 24 & 51 & -36 & -0.706 & 6 \\
\hline
\end{tabular}

Source: Primary data

Table 4E. Problem of Finance

\begin{tabular}{|c|c|c|c|c|c|c|c|c|c|}
\hline \multicolumn{10}{|c|}{ Engineering and Allied industries } \\
\hline Finance problems & Very High & High & Normal & Low & Very Low & $\mathbf{N}$ & SC & Co-eff. & Rank \\
\hline $\begin{array}{l}\text { Non-availability of fixed } \\
\text { capital }\end{array}$ & 9 & 12 & 8 & 7 & 5 & 41 & 13 & 0.317 & 2 \\
\hline High Rate of interest & 7 & 10 & 12 & 6 & 6 & 41 & 6 & 0.146 & 3 \\
\hline $\begin{array}{l}\text { Non-availability of finance } \\
\text { in time }\end{array}$ & 12 & 11 & 9 & 4 & 5 & 41 & 21 & 0.512 & 1 \\
\hline Penal interest & 7 & 8 & 6 & 11 & 9 & 41 & -7 & -0.171 & 5 \\
\hline Others & 3 & 9 & 9 & 13 & 7 & 41 & -12 & -0.293 & 6 \\
\hline
\end{tabular}

Source: Primary data

Tables $4 \mathrm{~A}$ to $4 \mathrm{E}$ exhibits that 'charging penal rate of interest' is a serious problem for Agro based industries and hence ranks first with a co-efficient of 0.450 . 'Non-availability of fixed capital' happens to be a threat to Chemical based industries with a co-efficient of 1.050 and to Mineral based industries with a co-efficient of 0.490 as both the industries have registered the first rank to this problem. However, the same problem has been ranked second by Agro based industries with a co-efficient of 0.439 , Textile based industries with a co-efficient of 0.277 and by Engineering and Allied industries with a co-efficient of 0.317 . 'Inadequate finance' has been ranked third by Chemical based industries, Textile based industries and Mineral based industries with a co-efficient of $0.500,0.108$ and 0.157 respectively. 'Non-availability of finance' has been assigned the fourth place by all the industries except Engineering and Allied industries for which it hailed to be the first and foremost problem with a co-efficient of 0.512 . 'High rate of interest' has been a serious problem for Textile based industries as it ranks first with a co-efficient of 0.346 . The same problem has ranked second for Chemical based and Mineral based industries, while it is given the third rank in case of Agro based, and Engineering and Allied industries.

\section{Conclusion and Suggestions}

The main purpose of the study is to investigate empirically how the entrepreneurs managed the micro, small and medium enterprises and what are the various problems faced by these enterprises. The study has revealed that the major hurdles like financial constraint, issues relating to power and raw material 
procurement as experienced by the MSMEs need to be more effectively dealt with by the government to redress them. Further, the study has also disclosed that the overall globalised business environment of India has been on an average favourable for the growth of micro and small scale industries as confirmed by the performance parameters of the number of working enterprises, employment generated and the market value of investment in fixed assets. Since most of the enterprises also complained about the non-availability of skilled labour, the government needs to look into this matter meticulously. Simple and clear policies, and schemes and subsidies simple in execution are to be made so that these enterprises can perceive and utilize to their benefit and growth augmenting the overall economic development of our country.

\section{References}

1. Available from: https://msme.gov.in/sites/default/files/MSME_ at_a_GLANCE_EN_0.pdf.

2. Sangita G Patil, Chaudhari PT. Problems of Small Scale Industries in India. International Journal of Engineering and Management Research. 2014 April; 4(2):19-21. ISSN No. 2250-0758.

3. Vasu MS, Jayachandra K. Growth \& Development of MSMEs in India: Prospects \& Problems. Indian Journal of Applied Research. 2014 May; 4(5). ISSN-2249-555X.

4. Shiraleshatti AS. Prospects and Problems of MSMEs in India - A study. International Journal of in Multidisciplinary and Academic Research (SSIJMAR). July-August; 1(2):17. ISSN 2278-5973.
5. Rajib Lahiri; Problems and Prospects of Micro, Small and Medium enterprises (MSMEs) India in the era of Globalization. Available from: www.rtc.bt/Conference/2012-10.../6.

6. Padmasani Karthika S. A study on Problems and Prospects of Micro, Small and Medium scale Enterprises in textile Exports with special reference to Tirupur and Coimbatore district. IJAMBV. 2013 Oct-Dec; 1(1). ISSN 2348-1382.

7. Nishanth P, Zakkariya KA. Barriers faced by Micro, Small \& Medium enterprises in raising finance. Abhinav National Monthly Referred Journal of Research in Commerce and Management. 2014 May; 3(5):39-46. ISSN - 2277-1166.

8. Neeru Garg. Micro Small and Medium enterprises in India: Current Scenario and Challenges. Paripex-Indian Journal of Research. 2014; 3(9):11-13.

9. Suneetha Kand Sankaraiah T. Problems of MSMEs and Entrepreneurs in Kadapa District. IOSR Journal of Economics and Finance (IOSRJEF). 2014 Mar-Apr; 3(2): 31-37. Version I.

10. Aruna NH. Problems Faced By Micro, Small and Medium Enterprises - A Special Reference to Small Entrepreneurs in Visakhapatnam. IOSR Journal of Business and Management (IOSR-JBM). 2015 Apr; 17(4):43-9. e-ISSN: 2278-487X, p-ISSN: 2319-7668.

11. Israr Ahmed. Problems and Prospects of Micro, Small and Medium Enterprises in Jammu and Kashmir. EPRA International Journal of Economic and Business Review Research Paper IC Value: 56.46. 2017 May; 5(5).

12. Available from: https://msme.gov.in/sites/default/files/MEME\%20 ANNUAL\%20REPORT\%202015-16\%20ENG.pdf. 